\title{
Analysis of Estrogen Effects on Eruption of Rat Molars
}

\author{
Análisis de los Efectos del Estrógeno en la Erupción de Molares de Rata
}

Livia Fiorim de Lima-Pansini; Nayra de Souza Carvalho Lima; Natan Oliveira Guss; Izabela Sinara Silva Alves; Letícia Nogueira da Gama-de-Souza; Jones Bernardes Gracelli; Marcos da Silva Pacheco \& Karla Loureiro Almeida Coburn

LIMA-PANSINI, L. F.; LIMA, N. S. C.; GUSS, N. O.; ALVES, I. S. S.; GAMA-DE-SOUZA, L. N.; GRACELLI, J. B.; PACHECO, M. S. \& COBURN, K. L. A. Analysis of estrogen effects on eruption of rat molars. Int. J. Odontostomat., 13(4):418-427, 2019.

ABSTRACT: Tooth eruption requires resorption of the alveolar bone interposed between the tooth germ and the oral mucosa (coronal bone). The cells responsible for bone resorption are the osteoclasts and their activity can be reduced or inactivated by estrogen hormone. We aimed to investigate the effects of estrogen on the process of tooth eruption in rats. Thirty-three Wistar rats, aged two-to-17-days, were divided into control, sham and estrogen-treated groups. After daily injections with estrogen, the animals were euthanized and the jaws removed and processed for histological analysis. We performed clinical examination, morphological analysis, quantification of the number of osteoclasts on the surface of the coronal bone and immunohistochemical analysis of estrogen receptor type alpha $(E R \alpha)$. Estrogen therapy was effective, which could be confirmed by the higher estrogen plasma levels on treated animals. However, it had no effect on tooth development or tooth eruption. Progressive bone resorption was observed and the number of osteoclasts on coronal bone was not affected on hormoneinjected animals, allowing tooth to erupt at the same time observed in untreated animals. Immunohistochemistry for ER $\alpha$ confirmed the presence of this type of receptor in osteoclasts, osteoblasts and osteocytes. Taken together, our results showed that estrogen stimulation was not sufficient to decrease the number of osteoclasts on the coronal bone, supporting the idea that, although estrogen may have a protective activity on bone resorption, this may not apply to the alveolar bone that is meant to be resorbed during eruptive process.

KEY WORDS: tooth eruption, bone resorption, estrogen, osteoclasts.

\section{INTRODUCTION}

Tooth eruption is the process that allows the tooth to emerge into the oral cavity once the alveolar bone and soft tissues interposed between the tooth germ and oral cavity are removed (Nanci, 2008). Bone remodelling is believed to be necessary for the eruption process, and involves the deposition of bone at the base of the alveolar bone crypt that surrounds the tooth germ and the resorption of the alveolar bone that forms the upper portion of the bone crypt (coronal bone) (Wise \& King, 2008). As the bone is resorbed by the action of cells responsible for bone degradation, the osteoclasts, the speed of the eruption process increases (Ferraris \& Muñoz, 2006; Nanci; Wise, 2008).

The formation of osteoclasts depends on the activation of various cells, such as monocytes and macrophages, and molecules that work in chemotaxis and fusion of mononuclear precursors derived from bone marrow. Important molecules-such as interleukin-1 alpha (IL-1 $\alpha$ ); tumour necrosis factor alpha (TNF- $\alpha$ ); colony stimulating factor-1 (CSF-1); receptor activator of nuclear factor kappa $\beta$ (RANK) and its ligand, the receptor activator of nuclear factor kappa $\beta$ (RANKL); and osteoprotegerin (OPG), a competitor of RANK-are essential factors in osteoclast formation (Wise et al., 2002; Wise, 2008, 2009; Florencio-Silva et al., 2015). Among the factors involved in the process, the RANK/RANKL/OPG pathway is for many the main route of osteoclast formation (Wise et al., 2000; Bord et al., 2003).

Two peaks of osteoclast formation were observed during tooth eruption in rat molars, a major one on the third postnatal day (Liu et al., 2005; Ferraris \& Muñoz; Wise, 2009), and another at about days nine and 11 (Liu et al., 2005). These peaks ensure the 
osteoclast formation required for resorption of alveolar bone and formation of the eruptive pathway (Liu et al., 2005; Wise, 2009).

Studies have shown that osteoclastic activity may be reduced or even inactivated by the influence of estrogen (Kameda et al., 1997; Väänänem, 2005; Faloni et al., 2007; Florencio-Silva et al.; Liu et al., 2015; Macari et al., 2015). This hormone can inhibit, for example, the production and secretion of molecules essential for osteoclast formation and activity, such as IL-1 $\alpha$, TNF- $\alpha$ (Pacifici, 1996; Macari et al.), macrophage colony stimulating factor (M-CSF) (Aubin \& Bonnelye, 2000; Srivastava et al., 2001) and RANKL (Srivastava et al.; Hofbauer \& Schoppet, 2004; Liang et al., 2008; Florencio-Silva et al.; Liu et al., 2015; Macari et al.), besides stimulating the production of OPG (Aubin \& Bonnelye; Saika et al., 2001; Bord et al., 2003; Hofbauer \& Schoppet; Liang et al.; FlorencioSilva et al.; Liu et al., 2015; Macari et al.). In addition, there is evidence that this hormone acts directly on osteoclasts via specific receptors, resulting in apoptosis of these cells (Kameda et al.; Crusodé de Souza et al., 2009; Florencio-Silva et al.). Two types of receptors for estrogen, alpha $(\alpha)$ and beta $(\beta)$, are found in different cells of the bone tissue, including osteoclasts. Also, as a direct effect on osteoclasts, estrogen inhibits the proteases responsible for bone degradation, such as Cathepsin K (Kameda et al.; Parikka et al., 2001; Florencio-Silva et al.) and metaloproteinase-9 (MMP9) (Faloni \& Cerri, 2007; Florencio-Silva et al.).

In the present study, we aimed to investigate the effects of estrogen administration on tooth eruption using rat molars. Since an anti-osteoclastic activity has been credited to estrogen, and tooth eruption depends partly on the osteoclastic activity, it is reasonable to expect that estrogen could interfere with the eruptive process. Rat molar is a very useful model for tooth eruption studies, since is a tooth of limited eruption, such as human dentition, and therefore the results can be translated to improve the current knowledge on human dental eruption process.

\section{MATERIAL AND METHOD}

This work was performed according to the Ethical Principles of Animal Experimentation adopted by the Ethics Committee on Animal Use of the Federal University of Espirito Santo, Brazil (CEUA-UFES), being approved on 07/01/2011, under license number 006/2011.
Thirty and three female Wistar rats (Rattus norvegicus), aged two to 17 days, were used in this study. The animals were provided by the Health Sciences Center facility and were maintained at constant room temperature $\left(22-24{ }^{\circ} \mathrm{C}\right)$ under a $12: 12$ light/dark cycle. All animals used in this study were still being breastfed, therefore were allowed to be kept with their mother, in polypropylene cages, with free access to water and food (Labina, Purina, Brazil). Health status of all animals was monitored daily until the end of the experiments.

The animals were divided in three groups: $\mathrm{G} 1$ (12 animals), G2 (12 animals) and G3 (nine animals). From the $\mathrm{G} 1$ animals, six rats beginning at two days of age were daily injected subcutaneously with estrogen (17-b-oestradiol-Sigma-Aldrich Co., St. Louis, MO, USA) diluted in corn oil for seven days. Three received a dose of $62.5 \mu \mathrm{g} / 100 \mathrm{~g}$ of weight, and three were injected with $125 \mu \mathrm{g} / 100 \mathrm{~g}$ (Faloni et al.) of weight. Three sham animals of the same age were injected only with corn oil, according to the same protocol, and three animals of the same age were used as noninjected controls. Twenty-four hours after the last injection, at nine days of age, the injected and noninjected animals were anesthetized by intraperitoneal injection with ketamine $(30 \mathrm{mg} / \mathrm{kg})$ and xylazine $(3 \mathrm{mg} /$ $\mathrm{kg}$ ), and clinical examination of the oral mucosa was performed. The animals also had their blood sample collected to determine the concentration of estrogen plasma levels, and then were euthanized by decapitation and their jaws removed for histological processing. The same procedure was performed with the $\mathrm{G} 2$ animals, except that the treatment initiated with four-day-old rats, which were euthanized when they were 11 days old. For the $\mathrm{G} 3$ animals, six rats beginning at four days of age, were injected daily for seven days with estrogen diluted in corn oil, three with a dose of $62.5 \mu \mathrm{g} / 100 \mathrm{~g}$ of weight, and three with a dose $125 \mu \mathrm{g} /$ $100 \mathrm{~g}$ of weight. Animals of this group were injected from the fourth to the $10^{\text {th }}$ day of life; they were however, euthanized at 17 days of life. Three animals of the same age were used as non-injected controls, to compare the timing of molar eruption.

Preparation for Histological Analysis: The removed jaws were dissected and the fragments containing the first molar were fixed at room temperature for 48 hours in $4 \%$ formaldehyde solution buffered with $0.1 \mathrm{M}$ sodium phosphate, $\mathrm{pH}$ 7.2. Next, specimens were decalcified for 40 days in $7 \%$ EDTA solution containing $0.5 \%$ formaldehyde buffered with $0.1 \mathrm{M}$ sodium phosphate, $\mathrm{pH}$ 7.2. and processed to be embedded in 
paraffin. The paraffin blocks containing the specimens were submitted to microtomy to obtain non-serial sections with $5 \mathrm{~mm}$ thickness. The histological sections were deparaffinized, rehydrated and stained with Hematoxylin and Eosin (HE). These sections were used for quantification of the number of osteoclasts adhered to the alveolar bone surface and general analysis of the morphological aspect of the tooth and surrounding tissues throughout the eruption process.

Immunohistochemistry Assay:To assess the expression of estrogen receptor $\alpha(E R \alpha)$ in bone cells, $3 \mu \mathrm{m}$-thick slices were obtained and processed for immunohistochemistry. The sections were deparaffinized, followed by diaphanization and rehydration. The formic pigment was removed with ammonium hydroxide solution (10\%) in ethanol (95 $\%$ and washed with $\mathrm{H}_{2} \mathrm{O}_{2}$ /Metanol to eliminate endogenous peroxidase activity. Antigen recovery was performed using a citrate buffer solution (10 mM citric acid and $0.05 \%$ Tween 20 with $\mathrm{pH}$ 6), heated between $90^{\circ} \mathrm{C}$ and $95^{\circ} \mathrm{C}$ for 40 minutes. The primary antibody used was anti-Estrogen Receptor $\alpha$ (MC-20: sc-542, Santa Cruz Biotechnology, Dallas, TX, USA), diluted 1:100 in PBS and incubated overnight in a humidified chamber at $40 \mathrm{C}$. After PBS washing, the immunoreaction was detected using a mouse probe (MACH 4 Universal AP Probe-Biocare

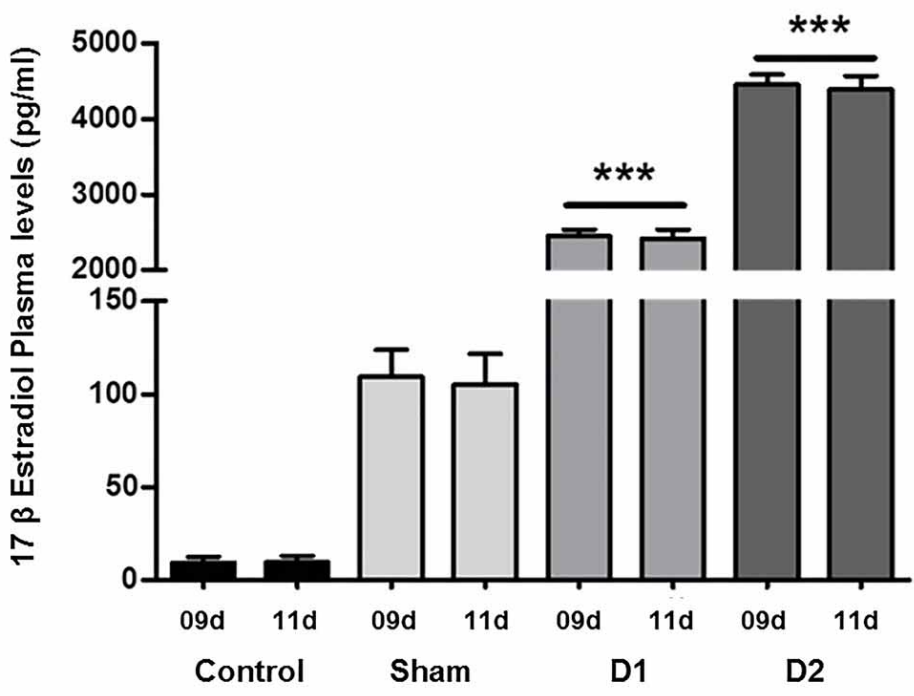

Fig. 1. 17bEstradiol plasma levels are elevated in estrogen injected animals. Estradiol plasma levels on nine-days-old animals were: $9.3 \pm 3.2 \mathrm{pg} / \mathrm{ml}$ (control), $110.8 \pm 14.5 \mathrm{pg} / \mathrm{ml}$ (sham), $2448.2 \pm 90.6 \mathrm{pg} / \mathrm{ml}$ (injected with estrogen D1 $=62.5 \mu \mathrm{g} / 100 \mathrm{~g}$ ) and $4451.0 \pm 134.8 \mathrm{pg} / \mathrm{ml}$ (injected with estrogen D2 $=125 \mu \mathrm{g} / 100 \mathrm{~g}$ ). Estradiol plasma levels on 11- days-old animals were, respectively: $9.5 \pm 3.5 \mathrm{pg} / \mathrm{ml}, 105.0 \pm 16.5$ $\mathrm{pg} / \mathrm{ml}, 2414.7 \pm 119.5 \mathrm{pg} / \mathrm{ml}, 4384.0 \pm 181.6 \mathrm{pg} / \mathrm{ml}$. ${ }^{* *} \mathrm{p}<0.05$.
Medical LLC, Pacheco, CA, USA) for 15 minutes and MACH 4 HRP Polymer (MACH 4 MR AP PolymerBiocare Medical LLC, Pacheco, CA, USA) for 30 minutes in a humidified chamber. As a negative control, the incubation step with primary antibodies was performed using an incubation step with non-immune serum. DAB (3.3-diaminobenzidine tetrahydrochloride, Sigma-Aldrich, St. Louis, MO, USA) was used to develop the peroxidase activity, and the slides were counterstained with Mayer's Hematoxylin and coverslipped.

Histomorphometric Analysis: The slides were examined under light microscope (Olympus AX70, Olympus America Inc., Melville, NY, USA) with Olympus UPlan FI 20x / 0.50 objective lenses. The selected sections were analyzed and photographed with AxioCam ERc5s (Carl Zeiss Vision GmbH, Jena, Germany) and AxioVision Release 4.8.2 (Carl Zeiss Vision $\mathrm{GmbH}$, Jena, Germany) and saved in TIF and ZIV formats.

The number of osteoclasts on the coronal bone surface was quantified by a single researcher. Cell morphology was used as criteria for identifying the osteoclast, i.e., the presence of acidophilic multinucleated and vacuolated cells on the alveolar bone surface. This analysis was performed using a $40 x$ objective lens. The sections processed by immunohistochemical method were analyzed and the ER $\alpha$ expression at the bone cells was examined. Osteoclasts and osteoblasts, positive or not for $\mathrm{ER} \alpha$ expression, were identified and quantified.

Statistical Analysis: All statistical analyses were performed using GraphPad software (GraphPad Software, Inc. La Jolla, CA, USA) and were considered statistically significant if $p<0.05$. The data were subjected to MannWhitney and Kruskal-Wallis nonparametric tests.

\section{RESULTS}

Hormonal Dosage: Blood analysis showed elevated estrogen plasma levels on injected rats, compared to control animals. Sham and non-injected animals also exhibited estrogen levels in the plasma, although to a lesser extent (Fig. 1). 

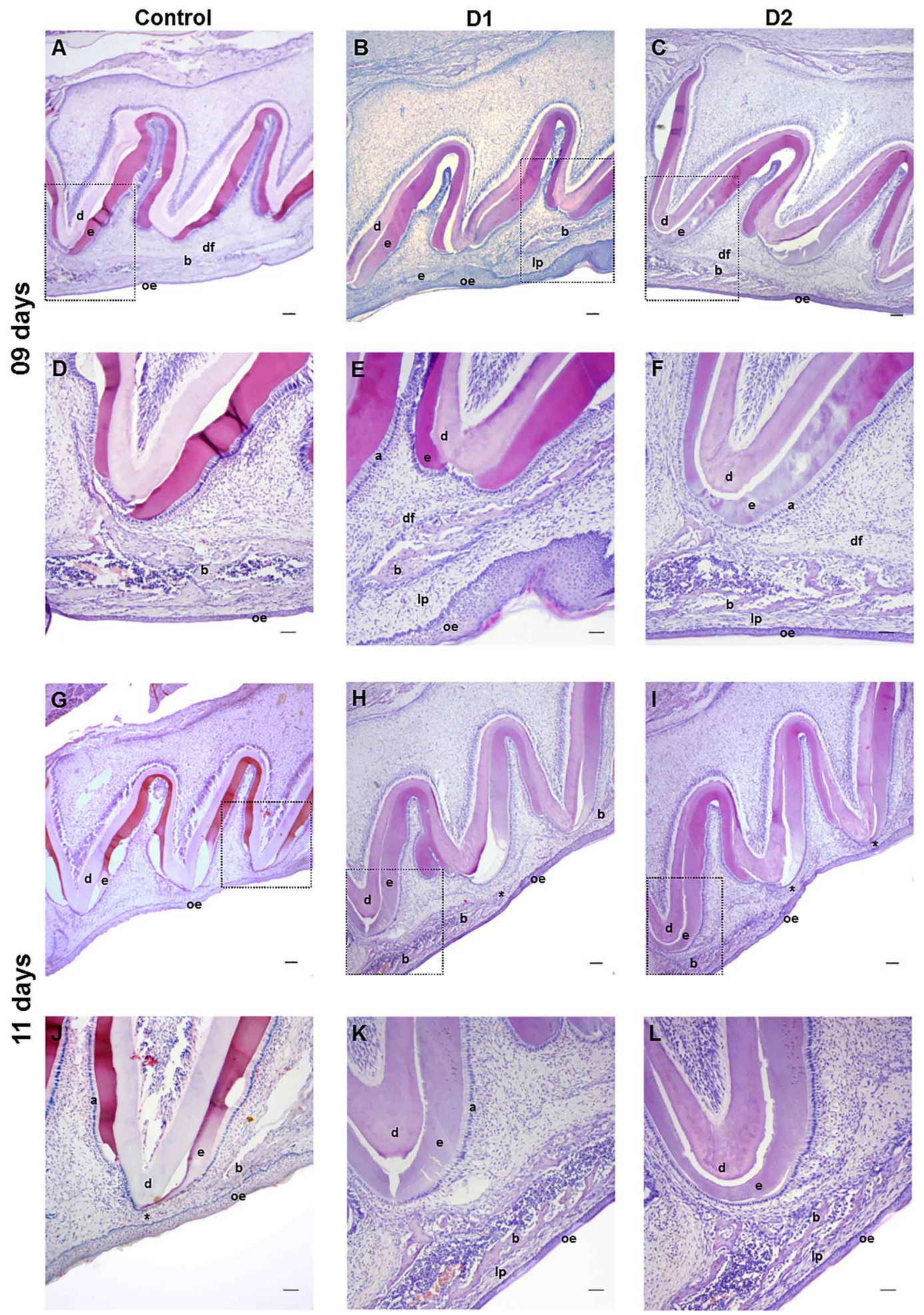

Fig. 2. Histological analysis of tooth and surrounding tissues shows no differences in estrogen injected animals. A, D, G, J: control animals, B, E, H, K: animals injected with estrogen at $62.5 \mu \mathrm{g} / 100 \mathrm{~g}$ (D1). C, F, I, L: animals injected with estrogen at $125 \mu \mathrm{g} / 100 \mathrm{~g}$ (D2). D, E and F are magnified images of the inserts seen on A, B, C, respectively (Nine-days-old animals). J, $\mathrm{K}$ and $\mathrm{L}$ are magnified images of the inserts seen on $\mathrm{G}, \mathrm{H}, \mathrm{I}$, respectively (11-days-old animals). At 11 days, in both treated and untreated animals, coronal bone resorption is observed (asterisks). HE staining, scale bar $100 \mu \mathrm{m}$ in A-C, G-I and $50 \mu \mathrm{m}$ in D-F, J-L. e (enamel); d (dentin); a (ameloblasts); df (dental folicle); b (bone); Ip (lamina propria), oe (oral epithelium). 
Morphological Analysis: Our histological analysis demonstrated that estrogen treatment seems not to affect tooth development, as the same features could be observed in treated and non-treated animals (Fig. 2). At nine days, all analyzed animals showed similar patterns of crown formation, with enamel and dentin deposition (Figs. 2 A-C). It is possible to observe a strip of bone tissue in the coronal region and the connective tissue of lamina propria between the alveolar bone and oral epithelium, which remain continuous (Figs. 2 D-F). The morphological features of tooth development at 11 days, in both groups, remain virtually unchanged compared to nine-day-old animals (Figs. $2 \mathrm{G}-\mathrm{I}$ ), except by the mature aspect of enamel, which leads to its loss during histological processing (Figs. $2 \mathrm{~J}-\mathrm{L})$.

Quantification of Osteoclasts: Histological analysis of the coronal alveolar bone revealed the presence of osteoclasts leaning on the bone surface, regardless of whether the animals were injected with estrogen (Figs. $3 \mathrm{~A}-\mathrm{C}$ ). There were no visible differences in the osteoclasts' morphology when comparing different groups. Sections stained with $\mathrm{HE}$ showed large, multinucleated and vacuolated cells in the sham group and groups treated with estrogen, in both doses (Figs. $3 \mathrm{~A}-\mathrm{C}$ ). Quantitative analysis indicated a reduced number of osteoclasts in estrogen-treated groups, compared with the control group and the sham group at the ages of nine days (Fig. 3D) and 11 days (Fig. 3E). However, statistical assessment of the data by the nonparametric Mann-Whitney test revealed no statistical significance $(p>0.05)$.

Immunohistochemical Analysis: Qualitative analysis of immunohistochemistry slides showed nuclear and/or cytoplasmic expression of ER $\alpha$ in osteoblasts and osteocytes in both sham and estrogen-treated animals, at both doses, on day nine (Figs. 4A-C) and day 11 (Figs. 4D-F). Osteoclasts
Sham

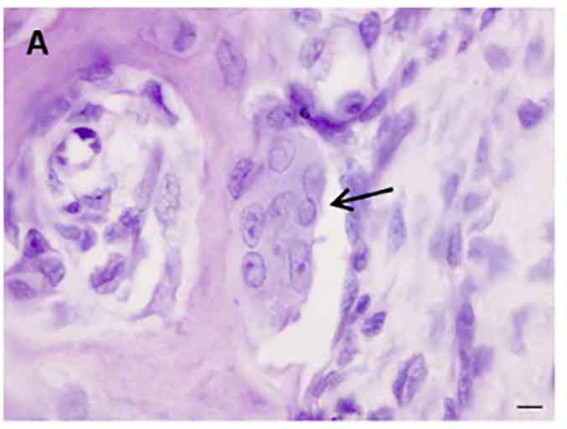

D

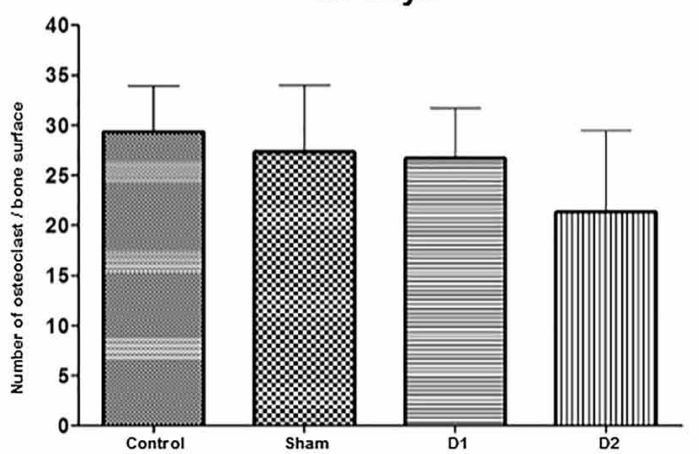

D1

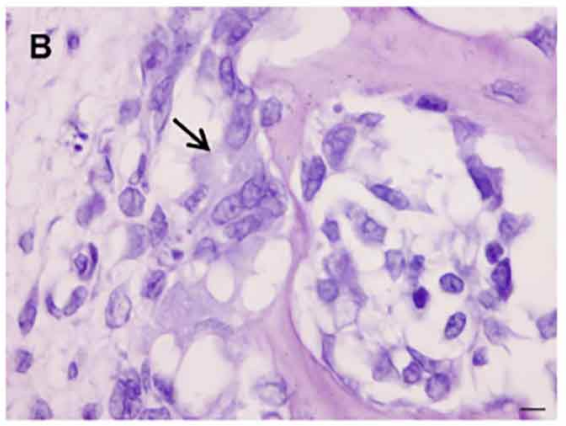

E

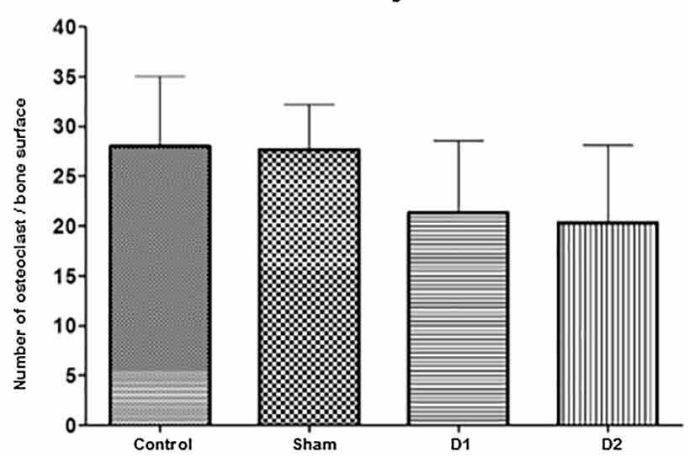

Fig. 3. Estrogen treatment does not affect osteoclasts count over the coronal bone surface during tooth eruption. A-C: Osteoclasts (arrows) at the coronal bone surface. HE staining, scale bar $5 \mu \mathrm{m}$. A: Sham. B: injected with estrogen D1=62.5 $\mu \mathrm{g} / 100 \mathrm{~g}$. C: injected with estrogen D2=125 $\mu \mathrm{g} / 100 \mathrm{~g}$. D-E: Quantification of osteoclasts at nine-days-old rats (D) and 11days-old rats (E). D: values of $29.33 \pm 4.61$ osteoclasts (control), $27.33 \pm 6.65$ (sham), $26.66 \pm 5.03$ (estrogen dose 1) and $21.33 \pm 8.14$ (estrogen dose 2). Values for means and standard deviation. $p>0.05$. E: values of $28 \pm 7$ osteoclasts (control), $27.66 \pm 4.50$ (sham), $21.33 \pm 7.23$ (estrogen dose 1) and $20.33 \pm 7.76$ (estrogen dose 2). Values for means and standard deviation. $p>0.05$ 


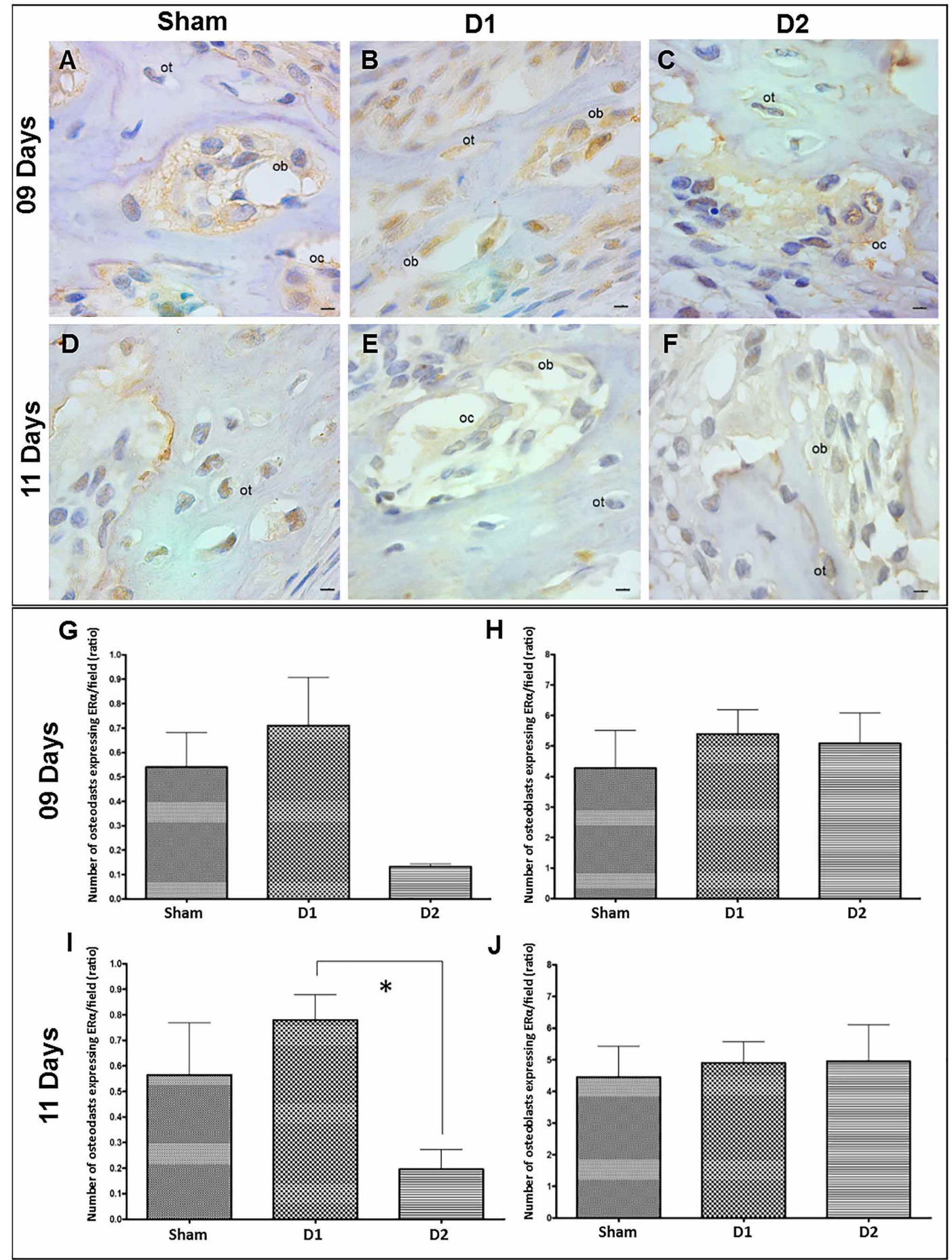

Fig. 4. Estrogen receptor a is expressed in bone cells during tooth eruption. Osteoblasts (ob), osteoclasts (oc) and osteocytes (ot) expressing Er $\alpha$ at coronal bone surface at nine-days-old animals (A-C) and 11-days-old (D-F). Scale bar: $5 \mu \mathrm{m}$. G: Osteoclasts expressing Er $\alpha$ at nine-days-old animals: $0.54 \pm 0.10$ (sham), $0.71 \pm 0.14$ (estrogen dose 1), and $0.13 \pm 0.0075$ (estrogen dose 2), values for means and standard deviation. $\mathrm{p}>0.05$. H: Osteoblasts expressing Ero at 09-days-old animals: $4.27 \pm 0.71$ (sham), $5.39 \pm 0.46$ (estrogen dose 1) and $5.08 \pm 0.58$ (estrogen dose 2), values for means and standard deviation. $p>0,05$. I: Osteoclasts expressing Er $\alpha$ at 11-days-old animals: $0.56 \pm 0.14$ (sham), $0.78 \pm 0.07$ (estrogen dose 1) and $0.19 \pm 0.05$ (for dose 2), values for means and standard deviation. * $p=0.0224$. J: Osteoblasts expressing Er $\alpha$ at $11-$ days-old animals: $4.45 \pm 0.56$ (sham), $4.90 \pm 0.38$ (estrogen dose 1) and $4.95 \pm 0.66$ (estrogen dose 2), values for means and standard deviation. $(p>0,05)$. 
were also observed displaying nuclear and cytoplasmic expression of ER $\alpha$ in all groups (Fig. 5). Quantitative analysis showed that the number of osteoclasts expressing $\mathrm{ER} \alpha$ tend to be reduced in animals treated with a higher dose of estrogen, when compared to sham animals $(p=0.0556)$ or animals treated with dose $1(p=0.0542)$ at nine days (Fig. 4G). Moreover, a significant reduction of the ER $\alpha$-expressing osteoclasts was detected at 11 days when injecting estrogen at dose 2 versus dose $1(p=0.0224)$ (Fig. 4I). Regarding the ER $\alpha$ expression on osteoblasts at nine (Fig. $4 \mathrm{H}$ ) and 11 days (Fig. $4 \mathrm{~J}$ ), the number of immunolabelled cells seemed to be higher on estrogen-treated animals, but such an increase was not statistically significant $(p>0.05)$.
Clinical and Histological Analysis of Tooth Eruption: A clinical examination of the oral cavity was performed on 17-day-old animals. It was possible to observe the partial exposure of the cusp tips in the oral cavity (Figs. 5A-C). The beginning of the eruption could be detected in treated and untreated animals, which leads us to state that no clinical differences were observed regarding the eruption process in rat molars. The histological analysis confirmed these data, since it was possible to detect, in both treated and untreated animals, the full resorption of the coronal bone, allowing the dental cusps to initiate the disruption of oral epithelium, which was discontinuous (Figs. 5 D-F). In the basal region, besides the continuity of bone formation, it was possible to observe the beginning of root development.
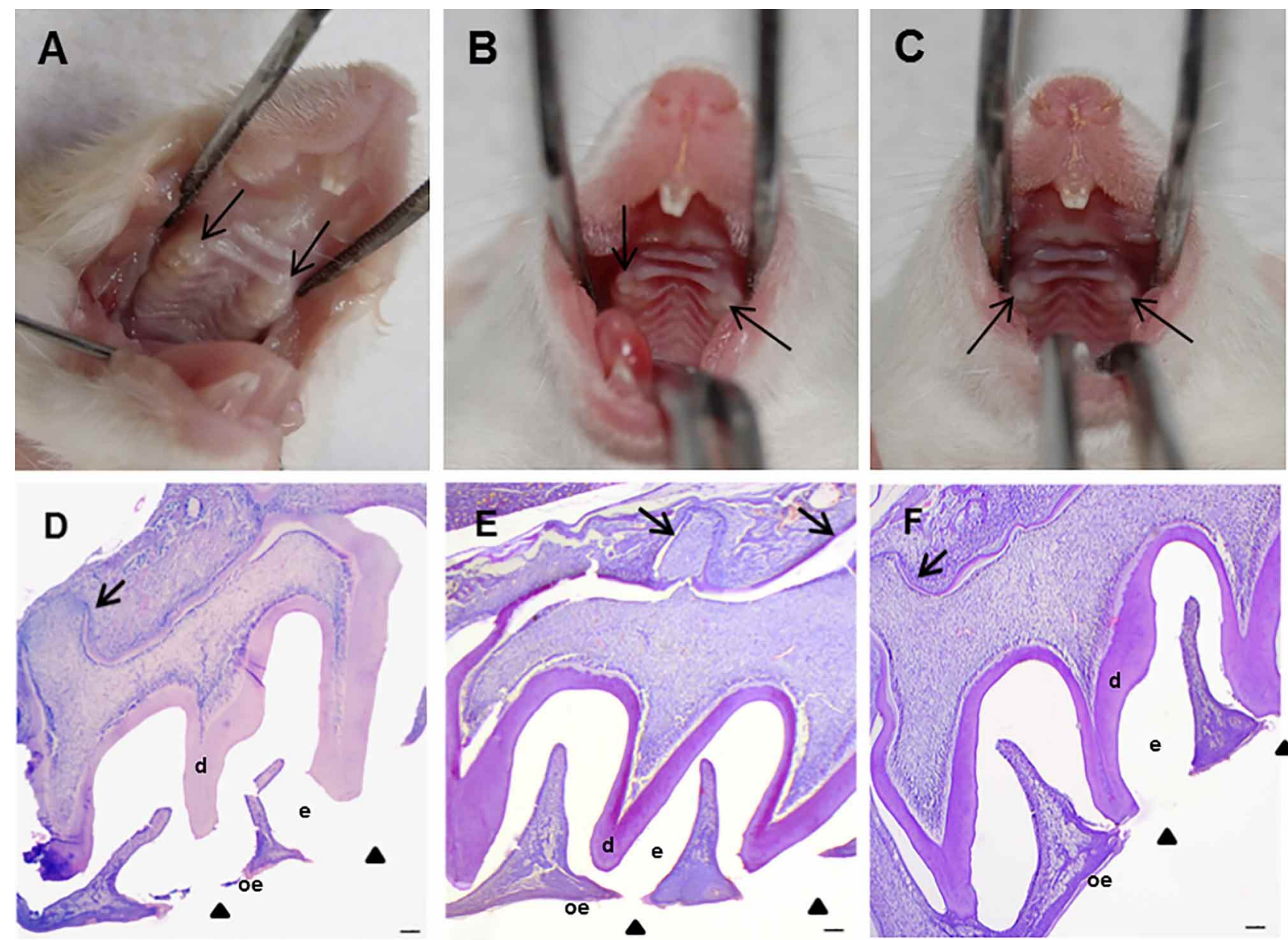

Fig. 5. Estrogen treatment dos not delay tooth eruption in rat molars. Clinical examination of the oral mucosa (A-C) and histological analysis of the eruptive process (D-F) in 17-day-old rats. A and D: control group; $B$ and $E$ : injected with estrogen dose 1; $\mathrm{C}$ and $\mathrm{F}$ : injected with estrogen dose 2. Clinical examination showed the beginning of the upper molars eruption (arrows) in the control group (A) and in the animals treated with estrogen (B and $C$ ). D-F: Cusp tips rupturing the oral epithelium (arrow heads) and root development (arrows). (d): dentin, (e) enamel space, (oe) oral epithelium. HE Staining, scale bar $100 \mu \mathrm{m}$. 


\section{DISCUSSION}

Regardless of the anti-osteoclastic role attributed to estrogen, our results demonstrated that the hormonal treatment was not able to retard tooth eruption. Microscopic analysis demonstrated that no differences could be detected between treated and untreated animals. The active bone resorption found in estrogentreated animals is a clear indication that osteoclastic activity was not impaired by the hormone treatment. In fact, the number of osteoclasts on the coronal bone surface was not reduced after estrogen injections, which could explain why treated animals had unaffected tooth eruption at 17 days of age, the same time as untreated animals. The treated animals that were euthanized at 17 days received estrogen injections from day four until 10 days old. It is possible that those seven days without treatment allowed a recovery response from bone cells, explaining why clinical eruption was not affected at day 17. However, animals that received injections and were euthanized right away did not show histological signs of delay on the eruption process either.

Animals treated with estrogen showed high hormone levels when compared with the control and sham groups, which confirms the effectiveness of the hormonal treatment performed in our study. Those levels were also higher than the hormone levels found by previous studies in adult female rats, which was $98+12 \mathrm{pg} / \mathrm{ml}$ (Gracelli et al., 2012). Sham animals showed a small increase in estrogen plasma levels when compared with the control group, which may be related to the administration of corn oil. Literature data confirm that vegetable oils may increase the concentration of estrogen in ovariectomized rats that received an oil-rich diet (Hassan \& Abdel-Wahhab, 2012; Hassan et al., 2013).

Our results contradict previous findings (Faloni et al.) that examined the effects of estrogen on the alveolar bone of rats. We believe that the bone tissue can behave and react in a distinct manner, depending on the region. The alveolar bone that surrounds erupted teeth is under constant remodelling to adapt to functional stress (Ferraris \& Muñoz; Nanci). Nevertheless, it is not intended to disappear, as its presence is required for supporting the tooth. The alveolar bone interposed between the tooth germ and the oral cavity, here called coronal bone, necessarily needs to be completely resorbed to ensure the success of the eruptive process (Marks \& Schroeder, 1996;
Bradaschia-Correa et al., 2007). Thus, it is possible that the coronal bone presented some compensatory mechanism to maintain the population of osteoclasts to ensure bone resorption and the consequent tooth eruption in estrogen-treated animals.

Another point to be considered is that the hormone treatment performed in our experiments comprises the two peaks of osteoclast production during the eruptive process in rats, at three and nine to 11 days of age (Wise et al., 2002; Wise \& King; Wise, 2009). The inhibitory effect that administration of high doses of estrogen could cause on osteoclasts at the coronal bone may have been balanced by the high production of these cells during this period, justifying the nonsignificant reduction in the number of osteoclasts observed in our study. Furthermore, it is important to note that the phenomenon of bone resorption for tooth eruption is not an isolated event. Bone apposition at the base of the tooth in formation occurs in parallel, and previous work has demonstrated its importance to the success of the eruptive process (Cahill \& Marks, 1980; Marks \& Cahill, 1984).

Studies have also shown that estrogen has an inverse role on osteoblasts to that observed on osteoclasts, i.e., estrogen stimulation has an antiapoptotic effect on osteoblasts (Crusodé de Souza et al.), which could increase the bone deposition activity at the base of the bone crypt. It has been shown that osteoblasts and osteocytes have specific receptors for estrogen (Bord et al., 2001; Michael et al., 2005; Florencio-Silva et al.), which could be confirmed by our immunohistochemical analysis that detected expression of $E R \alpha$ on those cells. What still raises controversies is the presence of this type of receptor on osteoclasts. Some studies indicate the presence of $\mathrm{ER} \alpha$ on osteoclasts (Kameda et al.; Bord et al., 2001; Michael et al.), while others claim that only the estrogen receptor $\beta$ is expressed in mature osteoclasts (Sørensen et al., 2006; Crusodé de Souza et al.). Our immunohistochemical analysis demonstrated both cytoplasmic and nuclear expression of $E R \alpha$ in osteoclasts. A possible explanation is that osteoclasts found in the coronal bone during the eruptive process are newly formed cells, which could justify the ER $\alpha$ expression. The reduced ER $\alpha$ expression detected at 11 days in osteoclasts injected with the higher dose of estrogen could be explained by receptor desensitization, in response to the high hormone levels (Carvalho, 2017). Thus, estrogen treatment did not affect osteoclasts at the coronal bone, allowing their resorptive activity and, consequently, tooth eruption. 
Taken together, our data demonstrated that the administration of estrogen was not able to decrease the number of osteoclasts on the alveolar bone interposed between the tooth and the oral mucosa (coronal bone), allowing bone resorption to take place at the same rate it happened on untreated animals. This could be clinically verified, as tooth eruption in treated animals occurred in normal time, and therefore, there was no delay in the process. Further studies should be performed to investigate possible metabolic differences between this alveolar bone and long bones, known to be susceptible to estrogen treatment.

\section{ACKNOWLEDGMENTS}

To Espirito Santo Research Foundation (FAPES), for providing graduate scholarship to LimaPansini (register number 55201849/2011) and Lima (register number 69952345/2015).

LIMA-PANSINI, L. F.; LIMA, N. S. C.; GUSS, N. O.; ALVES, I. S. S.; GAMA-DE-SOUZA, L. N.; GRACELLI, J. B.; PACHECO, M. S. \& COBURN, K. L. A. Análisis de los efectos del estrógeno en la erupción de molares de rata. Int. J. Odontstomat., 13(4):418-427, 2019.

RESUMEN: La erupción dental requiere la resorción del hueso alveolar interpuesto entre el germen dental y la mucosa oral (hueso coronal). Las células responsables de la resorción ósea son los osteoclastos y su actividad puede reducirse o inactivarse por la hormona del estrógeno. Objetivos: apuntamos a investigar los efectos del estrógeno en el proceso de la erupción dental en ratas. Treinta y tres ratas Wistar, de dos a 17 días de edad, se dividieron en grupos de control, Sham y se trataron con estrógenos. Los animales fueron eutanizados después del tratamento con estrógeno y se procesaron las mandíbulas para el análisis histológico. Se realizó el examen clínico, el análisis morfológico, la cuantificación del número de osteoclastos en la superficie del hueso coronal y el análisis inmunohistoquímico del tipo de receptor de estrógeno alfa $(E R \alpha)$. La terapia de estrógeno fue eficaz, lo que podría ser confirmado por los niveles plasmáticos más altos de estrógeno en los animales tratados. Sin embargo, no se observó ningún efecto sobre el desarrollo de los dientes o la erupción dental. Se observó una resorción ósea progresiva y el número de osteoclastos en el hueso coronal no se vio afectado en los animales inyectados con hormonas, permitiendo que el diente erupcionó durante el mismo período de tiempo observado en animales no tratados. La inmunohistoquímica para el ER $\alpha$ confirmó la presencia de este tipo de receptor en los osteoclastos, osteoblastos y osteocitos. Nuestros resultados mostraron que la estimulación del es- trógeno no fue suficiente para reducir el número de osteoclastos en el hueso coronal confirmando que, si bien el estrógeno puede tener una actividad protectora en la resorción ósea, esto puede no se aplica al hueso alveolar que está destinado a ser rerecurrido durante el proceso eruptivo.

PALABRAS CLAVE: erupción dental, resorción óssea, estrógeno, osteoclastos.

\section{REFERENCES}

Aubin, J. E. \& Bonnelye, E. Osteoprotegerin and its ligand: a new paradigm for regulation of osteoclastogenesis and bone resorption. Osteoporos. Int., 11(11):905-13, 2000.

Bord, S.; Horner, A.; Beavan, S. \& Compston, J. Estrogen receptors alpha and beta are differentially expressed in developing human bone. J. Clin. Endocrinol. Metab., 86(5):2309-14, 2001.

Bord, S.; Ireland, D. C.; Beavan, S. R. \& Compston, J. E. The effects of estrogen on osteoprotegerin, RANKL, and estrogen receptor expression in human osteoblasts. Bone, 32(2):136-41, 2003.

Bradaschia-Correa, V.; Massa, L. F. \& Arana-Chavez, V. E. Effects of alendronate on tooth eruption and molar root formation in young growing rats. Cell Tissue Res., 330(3):475-85, 2007.

Cahill, D. R. \& Marks, S. C. Jr. Tooth eruption: evidence for the central role of the dental follicle. J. Oral Pathol., 9(4):189-200, 1980.

Carvalho, C. R. O. Mecanismos de Ação Hormonal, In: Curi, R. \& Procopio, J. (Eds.). Fisiologia Básica. Rio de Janeiro, Guanabara Koogan, 2017. pp.673-94

Crusodé de Souza, M.; Sasso-Cerri, E. \& Cerri, P. S. Immunohistochemical detection of estrogen receptor beta in alveolar bone cells of estradiol-treated female rats: possible direct action of estrogen on osteoclast life span. J. Anat., 215(6):67381,2009

Faloni, A. P. S. \& Cerri, O. S. Mecanismos celulares e moleculares do estrógeno na reabsorção óssea. Rev. Odontol. UNESP, 36(2):181-8, 2007.

Faloni, A. P.; Sasso-Cerri, E.; Katchburian, E. \& Cerri, P. S. Decrease in the number and apoptosis of alveolar bone osteoclasts in estrogen-treated rats. J. Periodontal Res., 42(3):193-201, 2007.

Ferraris, M. E. G. \& Muñoz, A. C. Erupção Dentária. In: Ferraris, M. E. G. \& Muñoz, A. C. (Eds.). Histologia e Embriologia Bucodental. $2^{\text {th }}$ ed. Rio de Janeiro, Guanabara Koogan, 2006. pp.347-64.

Florencio-Silva, R.; Sasso, G. R.; Sasso-Cerri, E.; Simões, M. J. \& Cerri, P. S. Biology of bone tissue: Structure, function, and factors that influence bone cells. Biomed Res. Int., 2015:421746, 2015.

Gracelli, J. B.; Souza-Menezes, J.; Barbosa, C. M.; Ornellas, F. S.; Takiya, C. M.; Alves, L. M.; Wengert, M.; Feltran, G. da S.; CarusoNeves, C.; Moyses, M. R.; et al. Role of estrogen and progesterone in the modulation of CNG-A1 and Na/K+-ATPase expression in the renal cortex. Cell Physiol. Biochem., 30(1):16072,2012

Hassan, H. A. \& Abdel-Wahhab, M. A. Effect of soybean oil on atherogenic metabolic risks associated with estrogen deficiency in ovariectomized rats: dietary soybean oil modulate atherogenic risks in overiectomized rats. J. Physiol. Biochem., 68(2):247-53, 2012.

Hassan, H. A.; EL Wakf, A. M. \& EL Gharib, N. E. Role of phytoestrogenic oils in alleviating osteoporosis associated with ovariectomy in rats. Cytotechnology, 65(4):609-19, 2013.

Hofbauer, L. C. \& Schoppet, M. Clinical implications of the osteoprotegerin/RANKL/RANK system for bone and vascular diseases. JAMA, 292(4):490-5, 2004. 
Kameda, T.; Mano, H.; Yuasa, T.; Mori, Y.; Miyazawa, K.; Shiokawa, M.; Nakamaru, Y.; Hiroi, E.; Hiura, K.; Kameda, A.; et al. Estrogen inhibits bone resorption by directly inducing apoptosis of the boneresorbing osteoclasts. J. Exp. Med., 186(4):489-95, 1997.

Liang, L.; Yu, J. F.; Wang, Y. \& Ding, Y. Estrogen regulates expression of osteoprotegerin and RANKL in human periodontal ligament cells through estrogen receptor beta. J. Periodontol., 79(9):1745$51,2008$.

Liu, D.; Yao, S.; Pan, F. \& Wise, G. E. Chronology and regulation of gene expression of RANKL in the rat dental follicle. Eur. J. Oral Sci., 113(5):404-9, 2005.

Liu, Z.; Liu, L.; Kang, C.; Xie, Q.; Zhang, B. \& Li, Y. Effects of estrogen deficiency on microstructural changes in rat alveolar bone proper and periodontal ligament. Mol. Med. Rep., 12(3):3508-14, 2015.

Macari, S.; Duffles, L. F.; Queiroz-Junior, C. M.; Madeira, M. F.; Dias, G. J.; Teixeira, M. M.; Szawka, R. E. \& Silva, T. A. Oestrogen regulates bone resorption and cytokine production in the maxillae of female mice. Arch. Oral Biol., 60(2):333-41, 2015.

Marks, S. C. Jr. \& Cahill, D. R. Experimental study in the dog of the non-active role of the tooth in the eruptive process. Arch. Oral Biol., 29(4):311-22, 1984.

Marks, S. C. Jr. \& Schroeder, H. E. ToTooth eruption: theories and facts. Anat. Rec., 245(2):374-93, 1996.

Michael, H.; Härkönen, P. L.; Väänänen, H. K. \& Hentunen, T. A. Estrogen and testosterone use different cellular pathways to inhibit osteoclastogenesis and bone resorption. J. Bone Miner. Res., 20(12):2224-32, 2005.

Nanci, A. Movimento Dentário Fisiológico: Erupção e Exfoliação. In: Nanci, A. (Ed.). Tem Cate Histologia Oral: Desenvolvimento, Estrutura e Gunção. $7^{\text {th }}$ ed. Rio de Janeiro, Elsevier, 2008. pp.268-89.

Pacifici, R. Estrogen, cytokines, and pathogenesis of postmenopausal osteoporosis. J. Bone Miner. Res., 11(8):104351, 1996.

Parikka, V.; Lehenkari, P.; Sassi, M. L.; Halleen, J.; Risteli, J.; Härkönen, P. \& Väänänen, H. K. Estrogen reduces the depth of resorption pits by disturbing the organic bone matrix degradation activity of mature osteoclasts. Endocrinology, 142(12):5371-8, 2001.

Saika, M.; Inoue, D.; Kido, S. \& Matsumoto, T. 17beta-estradiol stimulates expression of osteoprotegerin by a mouse stromal cell line, ST-2, via estrogen receptor-alpha. Endocrinology, 142(6):2205-12, 2001.

Sørensen, M. G.; Henriksen, K.; Dziegiel, M. H.; Tankó, L. B. \& Karsdal, M. A. Estrogen directly attenuates human osteoclastogenesis, but has no effect on resorption by mature osteoclasts. DNA Cell Biol., 28(8):475-83, 2006.

Srivastava, S.; Toraldo, G.; Weitzmann, M. N.; Cenci, S.; Ross, F. P. \& Pacifici, R. Estrogen decreases osteoclast formation by downregulating receptor activator of NF-kappa $B$ ligand (RANKL)induced JNK activation. J. Biol. Chem., 276(12):8836-40, 2001.

Väänänem, K. Mechanism of osteoclast mediated bone resorption-rationale for the design of new therapeutics. Adv. Drug Deliv. Rev., 57(7):959-71, 2005.

Wise, G. E. \& King, G. J. Mechanisms of tooth eruption and orthodontic tooth movement. J. Dent. Res., 87(5):414-34, 2008.

Wise, G. E. Cellular and molecular basis of tooth eruption. Orthod. Craniofac. Res., 12(2):67-73, 2009.

Wise, G. E.; Frazier-Bowers, S. \& D'Souza, R. N. Cellular, molecular, and genetic determinants of tooth eruption. Crit. Rev. Oral Biol. Med., 13(4):323-34, 2002.

Wise, G. E.; Lumpkin, S. J.; Huang, H. \& Zhang, Q. Osteoprotegerin and osteoclast differentiation factor in tooth eruption. J. Dent. Res., 79(12):1937-42, 2000.
Corresponding author:

Karla Loureiro Almeida Coburn

27702 Wilson Run Lane

Fulshear

Texas 77441

UNITED STATES OF AMERICA

Email: karlaloureiro25@hotmail.com

Received: $30-03-2019$

Accepted:17-06-2019 